\title{
Impact of black yeasts on the durability of polyurethane foam in tropical conditions in Vietnam
}

\author{
Hoai Nguyen Thu ${ }^{*}$, Hong Do Thi Thu ${ }^{1}$, Cuong $\mathrm{Ngo} \mathrm{Cao}^{1}$, Thinh Do Tat ${ }^{2}$, and \\ V.N. Sereda ${ }^{3}$ \\ ${ }^{1}$ Institute of biotechnology, Vietnam Russia Tropical Center, 63 Nguyen Van Huyen Str., Vietnam \\ ${ }^{2}$ Institute of ecology, Vietnam Russia Tropical Center, 63 Nguyen Van Huyen Str., Vietnam \\ ${ }^{3}$ The Russian Academy of Sciences, Moscow, Russia
}

\begin{abstract}
Polyurethane (PU) is a material that is widely used in industries. However, tropical climatic conditions in Vietnam often make the durability of PU lower than temperate climatic conditions. One of the causes of this problem is the biodegradation of microorganisms. In this study, biological characteristics of black yeast on PU is evaluated, thereby, initially assessing the impact of black yeast on the durability of PU in tropical conditions. Ten strains of black yeast were isolated from used PU foam samples in Vietnam. These black yeast strains were tested for enzyme activity including: urease activity, protease activity, polyurethanase activity. There were two strains selected to identify based on sequence analysis of the ITS1/ITS2 region, they belong to genus Aureobasidium. VN1Y3 was strain selected for biodegradability testing of PU foam samples. After 28 days of testing, the PU foam samples that have been infected with black yeasts have a change compared to the control in terms of color, surface, tensile strength, elongation. Research results have showed the impact of black yeast on the durability of PU.
\end{abstract}

\section{Introduction}

Polyurethane (PU) is a synthetic polymer that is formed by condensation polymerization reaction between polyisocyanate and polyol having intramolecular urethane bonds. Urethanes are derivatives of carbamic acids which exist only in the form of their esters [1]. In tropical climatic conditions in Vietnam, PU often has a short durability due to many reasons such as temperature, humidity, radiation and biodegradation of microorganisms,... Biodegradation is a chemical degradation of polymers by the action of microorganisms, such as bacteria, yeasts and fungi. Microorganisms degrade the polymers like polyurethane by using it as a substrate for their growth. J. R. Crabbe et al. found four species of fungi including Curvularia senegalensis, Fusarium solani, Aureobasidium pullulans, and Cladosporium $\mathrm{sp}$. They were isolated based on their ability to utilize a colloidal polyester PU (Impranil DLN ${ }^{\mathrm{TM}}$ ) as the sole carbon and energy source [2]. Halim et al. tested the growth of several species of bacteria on PU military aircraft paint. The investigators

\footnotetext{
* Corresponding author: hongdt1009@gmail.com
} 
isolated four species of bacteria including: Acinetobacter calcoaceticus, Pseudomonas sp., Pseudomonas cepacia, and Arthrobacter globiformis . All species were capable of utilizing the polyurethane paint as a sole carbon and energy source with the exception of $P$. cepacia [3]. In addition, many authors argue that the biodegradation of PU is due to the activity of several extracellular enzymes, including polyurethanase [1-3]. In this paper, we described the biological characteristics of black yeast isolated from used PU foam samples and initially demonstrated their impact on the durability of PU.

\section{Materials and methods}

\subsection{Materials}

The materials that were used in this study included:

Samples: Used PU foam samples were collected in aircraft fuel compartment in Vietnam.

Media: Hansen medium [4], mineral medium with Impranil DLN'M (6 g/l) [1].

\subsection{Methods}

The study used the following methods:

Enrichment and isolation method: used PU foam samples are cut into small pieces of size $1.5 \times 1.5(\mathrm{~cm})$ and enriched in mineral medium with Impranil $\operatorname{DLN}^{\mathrm{TM}}(6 \mathrm{~g} / \mathrm{l})$ at temperature $28^{\circ} \mathrm{C}$ and shaking $250 \mathrm{rpm}$ for 7 days. Enrichment culture at the third inoculation was continued incubating on Hansen medium at temperature $28^{\circ} \mathrm{C}$ for 5 days to isolate black yeast colonies.

Determination of yeast morphology: Black yeasts were cultivated and differentiated by their macro and micro-morphologies according to Kurtzman et al.[5]

Determination of extracellular enzyme activity: the experiment was carried out by agar diffusion method according to Bauer et al.[4]

DNA extraction: the experiment was carried out using Zymo Research Kit (USA).

PCR: PCR is established using the ITS1/ITS4 primers and the corresponding heating programs.

Sequence analysis: The sequencing results were compared to related data in Genbank by the BLAST search on NCBI.

Biodegradation of PU test: according to ASTM G21-96 [6] and GOST 9049-91 [7].

Scanning electron microscopy: SEM was used to characterize surface modifications of polyurethane samples.

\section{Results and discussions}

\subsection{Isolation results}

Ten black yeast strains were isolated from used PU foam sample in Vietnam (Table 1). They had a variety of colonial and cell morphologies with typical characteristics of black yeast group, such as porous colonies, diverse colors, turning black when old (after about 7 days of culture), rod or oval cells, cells in chain or multiple faults. 
Table 1. Colony and cell of black yeast strains

\begin{tabular}{|c|l|l|l|l|l|}
\hline № & Strains & \multicolumn{1}{|c|}{ Morphology } & № & Strains & \multicolumn{1}{c|}{ Morphology } \\
\hline 1 & VN1Y1 & $\begin{array}{l}\text { Rounded, yellow } \\
\text { colony. Rod-shaped, } \\
\text { sequined cells }\end{array}$ & 6 & VN2Y1 & $\begin{array}{l}\text { Milky white colony. } \\
\text { Rod-shaped cells, } \\
\text { many faults. }\end{array}$ \\
\hline 2 & VN1Y2 & $\begin{array}{l}\text { Colony round, slightly } \\
\text { glossy, turning black } \\
\text { when old. Cells } \\
\text { spherical, budding. }\end{array}$ & 7 & VN2Y2 & $\begin{array}{l}\text { Creamy white colony, } \\
\text { turning black when } \\
\text { old. Rod-shaped cells, } \\
\text { many faults. }\end{array}$ \\
\hline 4 & VN1Y3 & $\begin{array}{l}\text { Milky white colony, } \\
\text { wrinkled, turning black } \\
\text { when old. Oval cell and } \\
\text { rod, budding. }\end{array}$ & 8 & VN2Y3 & $\begin{array}{l}\text { Yellow colony, the } \\
\text { center has the mind. } \\
\text { Rod cells, small, } \\
\text { many faults }\end{array}$ \\
\hline 5 & VN1Y5 & $\begin{array}{l}\text { Colony } \\
\text { wrinkled, turning black } \\
\text { when old. Cells } \\
\text { spherical, budding. }\end{array}$ & $\begin{array}{l}\text { Wrinkled, turning black } \\
\text { when old. Oval cells, } \\
\text { sequined. }\end{array}$ & VN2Y4 & $\begin{array}{l}\text { White colony, hard } \\
\text { surface. Rod cells, } \\
\text { small, many faults. }\end{array}$ \\
\hline
\end{tabular}

The morphology of colonies and cells of 10 strains of black yeast have complex differentiation. Many researchers believe that the complexity of the black yeast's life cycle (changes in colony color and cell shape that can occur during 3 weeks of culture) have led to grouping and identifying become less accurate. Therefore, to confirm the results, more biochemical tests and sequencing are needed [8]. In this study, an evaluation of enzyme activity and molecular identification was performed.

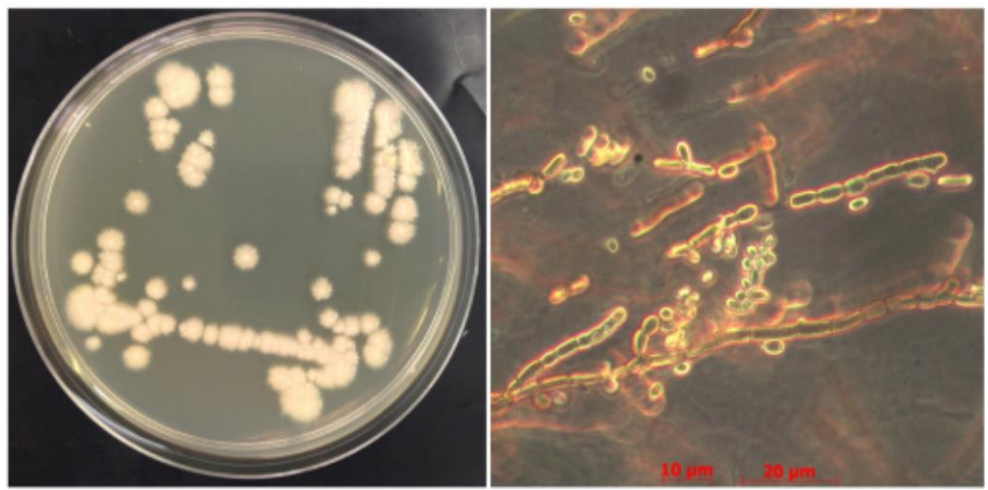

Fig.1. Colony (left) and cell (right) of strain VN1Y4

\subsection{Determination of enzyme activity}

The results showed that all strains had extracellular enzyme activity. In which, VN1Y3, VN1Y4 and VN2Y1 were the three strains with the highest polyurethanase activity, strain VN2Y1 and strain VN2Y4 had the highest protease activity, the urease activity of black yeast strains in this study was relatively low (except strain VN1Y3 ). VN1Y3 and VN1Y4 were the best enzyme activity strains, thus they continued to be identified by ITS1/ITS2 region sequences (Table 2 ). 
Table 2. Enzyme activity of black yeast strains

\begin{tabular}{|c|c|c|c|c|c|c|c|c|c|}
\hline № & Strains & PU & Pr & Ure & № & Strains & PU & Pr & Ure \\
\hline 1 & VN1Y1 & - & ++ & + & 6 & VN2Y1 & ++ & ++++ & - \\
\hline 2 & VN1Y2 & + & + & + & 7 & VN2Y2 & + & + & - \\
\hline 3 & VN1Y3 & ++ & ++ & ++ & 8 & VN2Y3 & - & - & + \\
\hline 4 & VN1Y4 & ++ & +++ & + & 9 & VN2Y4 & + & ++++ & - \\
\hline 5 & VN1Y5 & + & +++ & + & 10 & VN3Y3 & + & ++ & - \\
\hline
\end{tabular}

([+] positive, [-] negative; $\mathrm{PU}$ - polyurethanase, $\mathrm{Pr}$ - protease, Ure - urease)

Extracellular enzyme activity of microorganisms isolated from PU foam has been mentioned in many previous studies $[9,10]$. However, only a few studies have evaluated the polyurethanase activity of black yeast. Studies have also shown the role of polyurethanase in the use of PU materials by yeasts as carbon source for their growth [10]. Therefore, the research results can be considered as the first step to assess the impact of black yeast on the quality of PU during the use of this product.

\subsection{Molecular identification}

The sequence of ITS1/ITS2 of two black yeast strains (VN1Y3, VN1Y4) was sequenced based on primers ITS1 (5'-TCCGTAGGTGAACCTGCGG-3') and ITS4 (5'TCCTCCGCTTATTGATATGC-3'). Phylogenetic tree was established by comparing the sequencing results on Genbank using the BLAST search on NCBI (Fig. 2).

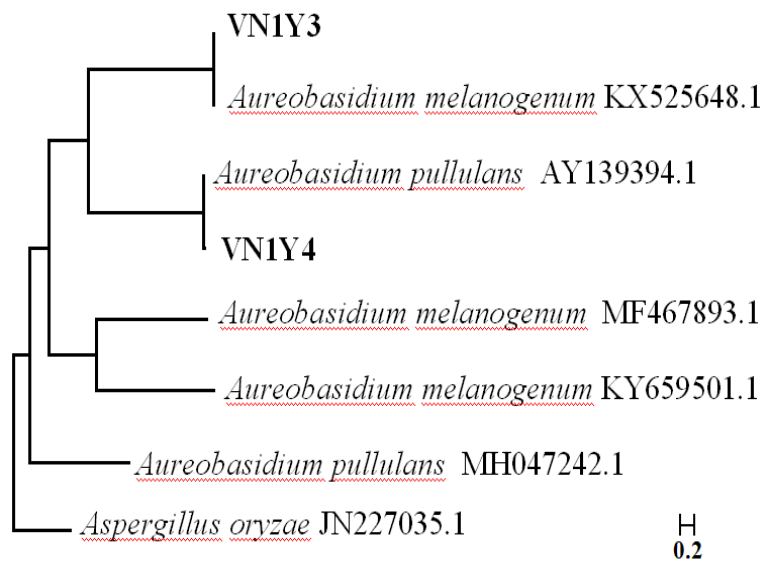

Fig.2 Phylogenetic tree of yeast, based on the ITS1/ITS2 region sequences

VN1Y3 and VN1Y4 a were closely related to species in the following order: $A$. melanogenum, A. pullulans. Combined with the results of analyzing the morphology of colonies, the morphology of cells and checking the extracellular enzyme activity of the black yeast strains in the above section (section 3.1 and 3.2), the results of identification by sequencing was completely reliable. These results were similar to the results of J.R. Crabbe et al. about the existence of yeast belonging to genus Aureobasiditum on PU foam [2].

\subsection{Biodegradation of PU test results}

VN1Y3 was the black yeast strain selected for biodegradation testing because it had high extracellular enzyme activity for all enzymes studied and determined to be closely related 
to species A. melanogenum (black yeast species was assessed as being capable of producing polymerases [11]). After 28 days of testing with strain VN1Y3, PU foam samples were changed in color, surface, tensile strength and elongation compared to the control PU foam.

\subsubsection{Colour of PU}

After drying, the PU foam sample tested with strain VN1Y3 has changed its color from light yellow to dark yellow (Fig. 3). The cause of this problem may be due to the yeast adhesion on the surface of PU and the PU material has been modified due to the growth of yeast. To clarify this problem, PU foam surfaces continue to be observed by scanning electron microscopes.

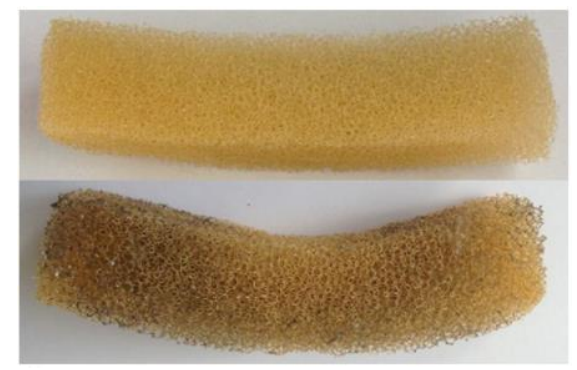

Fig.3 Colour of PU foam with VN1Y3 (below) and control (above)

\subsubsection{Surface of $P U$}

The surface of the PU foam after testing was observed by scanning electron microscopy at magnification 500x (Fig.4). Fig 4 showed the adhesion of yeast biomass on PU foam surfaces. Compared with the control under the same test conditions, it can be seen that the PU foam samples tested with VN1Y3 appear to have plaque on the PU surface, their fiber systems form dense networks on the foam surface. In addition, at higher magnifications, pits and dimples can be observed while the control PU foam had a smooth and flat surface after 28 days of testing.
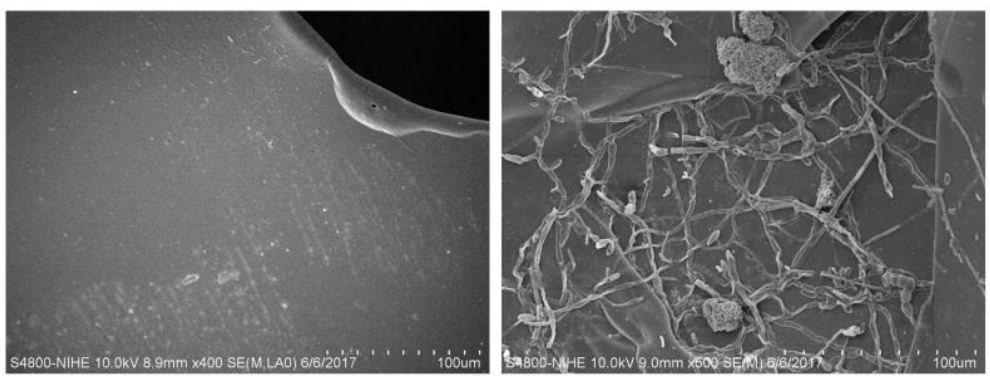

Fig. 4 Surface of control (left) and PU foam with VN1Y3 (right)

The results of this study are completely similar to those of T. H. Gary and A. Nakkabi et al. on the growth of microorganisms on PU. A. Nakkabi et al. observed a much net growth of the bacterium Bacillus safensis on the polyurethane surface after 7 days of testing [1]. T. H. Gary also suggested that microorganisms have used PU as a source of carbon and energy for their growth [10]. 


\subsubsection{Tensile strength and elongation of $P U$}

Many studies suggest that the extracellular enzymes of microorganisms can cut the chemical bonds of PU, thereby reducing their durability [3,10,12]. In this study, tensile strength and elongation of foam samples were checked by specialized equipment. The results showed that the presence of yeast VN1Y3 caused the tensile strength of PU foam sample was $4,9 \mathrm{~N} / \mathrm{cm}^{2}$ corresponding to $38,9 \%$ compared to the control $\left(12,6 \mathrm{~N} / \mathrm{cm}^{2}\right)$. The elongation was $175 \%$ while the control reaches $335 \%$. The results demonstrated the obvious impact of black yeast VN1Y3 on the durability of PU foam.

\section{Conclusions}

Ten strains of black yeast were isolated from used PU foam samples with biological characteristics that showed their significant impact on the durability of PU foam, especially the ability to produce polyurethanase. After 28 days of testing with black yeast VN1Y3, PU foam was changed in color, tensile strength and elongation compared to the control PU foam. In which, tensile strength decreases to $38.9 \%$. The strain VN1Y3 is closely related to species Aureobasiditum melanogenum.

This research has been supported by Project T 1.3 from The Scientific committee of Vietnam Russia.

\section{References}

1. A. Nakkabi, M. Sadiki, S. Ibnssouda, M. Fahim, Int. J. of Recent Advances in Multidisc. Res. 02, 4 (2015)

2. J.R. Crabbe, J.R.Campbell, L.Thompson, S.L. Walz, W.W. Schultz, Int. Biodeterior. Biodegrad. 33, 11 (1994)

3. E.S. Halim, W.M. Mahmoud, E.M. Davis, R.W. Coughlin, Int. Biodeterior. Biodegrad. 37, 11 (1996)

4. W. Bauer, W.M.M. Kirby, J.C. Sherris, Microbiol. and Medic., 45, 7 (1966)

5. C.P. Kurtzman, J.W. Fell, T. Boekhout, V. Robert, The yeasts: a taxonomic study (Elsevier, San Diego, 2011)

6. ASTM G21-13, Standard practice for determining resistance of synthetic polymeric materials to fungi (ASTM International, 2013)

7. GOST 9.049.91, Polymer materials and their components, Methods of laboratory tests for mould resistance to the effect of mold fungi.

8. S. Seyedmousavi, M. G. Netea, J. W. Mouton, W. J. G. Melchers, P. E. Verweij, G. S. Hooge, ASM journal, 17 (2014)

9. R. Gautam, A.S. Bassi, E.K. Yanful, E. Cullen, International Biodeterioration \& Biodegradation, 60, 5 (2007)

10. T. H. Gary, Recent Developments in Polymer Recycling, 24 (2011)

11. C. Gostincar, R. A. Ohm, T. Kogej, S. Sonjak, M. Turk, J. Zajc, P. Zalar, M. Grube, H. Sun, J. Han, A. Sharma, J. Chiniquy, C. Y. Ngan, A. Lipzen, K. Barry, I. V. Grigoriev, N. G. Cimerman, BMC Genomics, 14, 29 (2014)

12. R. S. Gisele, S. C. Armando, B. C. Francine, A. Eliane, L. O. Rodrigo, Polymer Degradation and Stability, 95, 9 (2010) 